Military Technical College Kobry Elkobbah, Cairo,

Egypt.

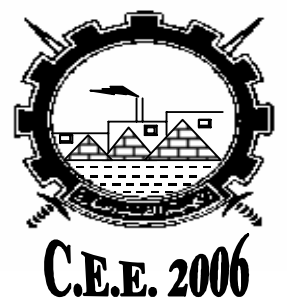

$3^{\text {rd }}$ International Conference

On

Chemical \& Environmental Engineering

\title{
PURIFICATION OF UNDERGROUND WATER FROM FERROUS AND MANGANOUS IONS USING ACTIVATED CARBON DERIVED FROM RICE HUSK (CASE STUDY)
}

\author{
Diafullah A. A. , Abdo. M. H. ** Moustafa M. E. ${ }^{* *}$, \\ Amin A. S. ${ }^{* * *}$ and Mohamed F. M.
}

\section{ABSTRACT}

To address questions of water quality and to suggest a local and available treatment process for iron and manganese removal, ground water samples w ere collected at 4-stations (I, II, III, IV) seasonally during March 2003 - Feb. 2004 and determined using atomic absorption spectrophotometer (AAS). The results showed that the concentrations of these ions are higher than the permissible levels. In this concern, treatment procedure was evaluated using activated carbon prepared by chemical activation of rice husk using $70 \% \mathrm{H}_{3} \mathrm{PO}_{4}$ at $500{ }^{\circ} \mathrm{C}$. Factors affecting adsorption process (e.g. contact time and sorbent mass) were examined. The results showed that the percent removal almost reaches $\geq 99 \%$ and in all cases the ion concentration after treatment is less than the permissible level. Adsorption isotherm indicates that the monolayer coverage is $0.357 \mathrm{~g}$ and $0.625 \mathrm{~g}$ of ferrous and Manganous per gram of sorbent respectively. In dynamic mode, the adsorption capacity (i.e., $\mathrm{C}_{\mathrm{e}} / \mathrm{C}_{\mathrm{o}}=50 \%$ or $\mathrm{Q}_{0.5}$ ) was $1 \mathrm{mg} / \mathrm{g}$ at flow rate 1 liter $/ \mathrm{min}$. and the column recycled at least five times and only needed $1 / 2 \mathrm{ml}$ of $\mathrm{KMnO}_{4}(0.06 \mathrm{M})$ for each regeneration step and no loss in sorbent per cycle should be considered. Therefore, activated carbon derived from rice husk may be considered as a better replacement technology for removal of $\mathrm{Fe}^{+2}$ and due to good efficiency in this application. The possible working adsorption mechanisms are discussed and confirmed by FTIR.

\section{KEY WORDS}

Purification, modified rice husk, under ground water, adsorption, ferrous, manganous ions and activated carbon.

\footnotetext{
Hot Lab. Center, Atomic Energy Authority,

** National Institute of Oceanography and Fisheries.

${ }_{* * * *}^{* *}$ Faculty of Science, Banha University,

Kaha Company for Chemical Industries, National Authority for Military Production.
} 


\section{INTRODUCTION}

According to figures recently issued by the world health organization, (WHO) an average of 50000 people die each day from diseases associated with bad water; one person about every two second [1].

Drinking water can come from either ground water sources (via wells) or surface water sources (such as river, lakes, and streams).

Iron and Manganese are common in groundwater supplies and the maximum contaminant levels (MCL) according to WHO is $0.3 \mathrm{mg} / \mathrm{l}$ and $0.1 \mathrm{mg} / \mathrm{l}$ of iron and manganese respectively [1-8].

Neither iron nor manganese poses health risks. Both in small concentrations are essential of human health. But the presence of significant iron and manganese in water supplies can create several problems: (i) Long time consumption of drinking water with high concentration of iron causes liver diseases, (ii) Higher concentration will give a water a medicinal or metallic taste, (iii) Cause corrosion and pipe blockages either directly, precipitating deposits or indirectly by providing favorable condition for growth of specific bacteria [3], (iv) Large concentrations of iron and manganese in water can cause troubles in domestic and industrial uses and (v) In extreme cases, iron and manganese interfere with culinary use, turning tea black and darkening boiled vegetables $[3,4]$

Because iron and manganese are chemically similar, they cause similar problems. Iron will cause reddish-brown staining of laundry, porcelain, dishes, utensils, and even glassware. Manganese acts in a similar way but causes a brownish-black stain. Soaps and detergents do not remove these stains, and the use of chlorine beach and alkaline builders (such as sodium carbonate) can actually intensify the stains $[3,4]$. Iron and manganese accumulations become an economic problem when water supply or softening equipment must be replaced. There are also associated increased energy costs, like pumping water through constricted pipes or heating water with heating rods coated with iron or manganese minerals.

There are many methods of iron and manganese removal (9-14): polyphosphate treatment that protect dissolved iron and manganese from reacting with oxygen and precipitate by trapping them in a complex molecule that is soluble in water, (ii) soluble iron and manganese can be exchanged for sodium on an exchange resin or zeolite, (iii) greensand filtration using the active Glauconate mineral. This clay mineral will form insoluble iron and manganese and it must be regenerated by $\mathrm{KMnO} 4$ for frequent uses, and (iv) chemical oxidation followed by filtration is accepted method of iron and manganese removal. In this concern, soluble iron and manganese begin to precipitate after contact $20 \mathrm{~min}$. with chlorine solution (oxidant). An additional advantage of using chlorination system is bacteria damage.

Concentration of iron and manganese when using the aforementioned methods of treatment is as follows: polyphosphate treatment (0-3 ppm); ion-exchange (softener) (0-10 ppm); Greensand filter (0-10 ppm) and chlorination (0 - > $10 \mathrm{ppm})$.

Approximately 100 million tones of rice husk is available annually for utilization in developing countries. However, the amount of rice husk available is far in excess of any local uses and thus has posed a disposal problem (15). 
Rice husk was chosen as an adsorbent in several water treatment processes due to suitable structure, insolubility in water, chemical stability, high mechanical strength and its local availability at almost no cost.

In the present study, a new method was suggested for iron and manganese removal from groundwater using activated carbon prepared from rice husk by chemical activation with $70 \% \mathrm{H}_{3} \mathrm{PO}_{4}$ and heat treatment at $773 \mathrm{~K}$. Factors affecting sorption process are studied in batch and column modes.

\section{EXPERIMENTAL}

i- Experimental design: The experimental part is divided into two main sections:

(i) the $1^{\text {st }}$ concerns with the regular routine analysis of the ground water samples in the four stations before and after traditional treatment. (ii) the $2^{\text {nd }}$ section concerns with the removal of $\mathrm{Fe}$ and $\mathrm{Mn}$ ions of a representative sample obtained from station I. Whereas, the treatment is depended on adsorption technique using activated carbon prepared from Rice Husk.

ii. Sampling: The sampling period form March 2003 to Feb. 2004. groundwater samples were collected seasonally from four stations as presented in Fig. 1 the capacity of each station is approximately $10,000 \mathrm{~m}^{3} /$ day. The groundwater samples were kept in well stoppered polyethylene plastic bottles (1 L capacity) and taken the notations I, II, III and IV before treatment and I', II', III' and IV' after treatment.

iii. Preparation of activated carbon: Rice Husk was chosen as a precursor for the preparation of active carbon by impregnation with $70 \% \mathrm{H}_{3} \mathrm{PO}_{4}$. The temperature was raised at the rate of $\left(50{ }^{\circ} \mathrm{C} / 5 \mathrm{~min}\right.$.) up to $500^{\circ} \mathrm{C}$ and hold at this temperature for 2.5 h. This carbon was taken RH-57 as notation.

iv. Treatment procedures: Factors affecting the adsorption process e.g. equilibrium time, batch factor, sorbent mass were studied. In all cases, $1 \mathrm{~L}$ of ground water was contacted with $0.008 \mathrm{~g}$ of $\mathrm{AC}$ in stoppered bottle. The conditions of each experiment were adjusted, then, the mixture was filtered and the samples were analyzed for iron and manganese concentration using AAS. Isotherm experiments were carried out using bottle point technique. Each sample was mixed with various quantities of $A C$ ranging from 0.002 to $0.01 \mathrm{~g}$ and agitated for $4 \mathrm{hrs}$ in case of iron and $5 \mathrm{hrs}$ in case of manganese at room temperature $\left(25 \pm 1^{\circ} \mathrm{C}\right)$. The concentration was measured in the filtrate using AAS (model: ZL8100 Schmitzu).

In all cases, the difference between the initial concentration $\left(\mathrm{C}_{\circ}\right)$ and the equilibrium concentration $\left(\mathrm{C}_{\mathrm{e}}\right)$ was calculated and used to determine the adsorptive capacity (qe) as follows: qe $=\mathrm{V}\left(\mathrm{C}_{\circ}-\mathrm{C}_{\mathrm{e}}\right) / \mathrm{M}$, Where $\mathrm{V}$ is the total volume of solute solution $(\mathrm{I})$, $\mathrm{M}$ the mass of adsorbent used $(\mathrm{g}), \mathrm{C}$. the initial concentration of the solute $\left(\mathrm{g} \mathrm{l}^{-1}\right)$, and $\mathrm{C}_{\mathrm{e}}$ is the residual concentration of the solute $\left(\mathrm{g}^{-1}\right)$

\section{RESULTS AND DISCUSSION}

$1^{\text {st }}$ section: The data listed in tables (1-4) describe the concentration levels of the physicochemical in (ppm) of the 4- stations ( I, II, III and IV) in the four seasons. Traditional treatment technique in the four stations was applied (aeration, oxidation, filtration and chlorination) and aimed to reduce the concentration of iron and manganese only to the permissible limits ( 1 and $0.5 \mathrm{ppm}$ ) respectively. But, it is well known that groundwater is not stable like surface water so the concentration of the constituents are varied seasonally. This variation is dependant on the solubility of 
these constituents and contamination of groundwater by rain and industrial wastewaters. As shown in tables (1-4), all parameters before and after treatment are cited within normal limits according to WHO and Egyptian specification except the following parameters:

1- iron and manganese levels before treatment exceeded the permiscible levels and thus treatment is a must.

2- Lead is out of limits (more than $0.05 \mathrm{mg} / \mathrm{l}$ ) in all stations at all seasons except station IV in the all seasons, station I at the autumn.

3- Iron and manganese after treatment are within limit of Egyptian specification except for manganese in station IV at the summer season.

4- TDS before and after treatment are within the normal limits ( $1200 \mathrm{mg} / \mathrm{l})$ except for station IV at all seasons. This may be due to contamination of wells with fertilizers and some industrial pollutants.

5- Similar observation is recorded for TS in station IV in the autumn and winter seasons.

\section{The $2^{\text {nd }}$ section :}

The physicochemical properties of $\mathrm{RH}-57$ are presented in table 5 . The pore size distribution by DFT is presented in Fig.2 and it shows a significant amount of micropores with the apparent bimodal distribution of pores in the microporous region with maxima at 1.1 and $1.7 \mathrm{~nm}$ respectively. The density function theory (DFT) method is applicable for the entire rangeof pore sizes accessible by the adsorptive molecule $\left(\mathrm{N}_{2}\right)$, which makes this technique very attractive compared to the commonly used BET method (16). The surface area and pore volume of RH- 57 are $419 \mathrm{~m}^{2} / \mathrm{g}$ and $0.213 \mathrm{ml} / \mathrm{g}$ respectively.

\section{Adsorption Experiments:}

Effect of agitation time: The time -profile of adsorption of $\mathrm{Fe}^{2+}$ and $\mathrm{Mn}^{2+}$ ions onto $\mathrm{RH}-57$ at room temperture $\left(25 \pm 1^{\circ} \mathrm{C}\right)$ is presented in Fig.3. Agitation time increases, cation removal also increases initially, but then gradually approaches a constant value, denoting attainment of an equilibrium. Obviously, the equilibrium was attained after shaking for about $4 \mathrm{~h}$ in case of $\mathrm{Fe}^{2+}$ and $5 \mathrm{~h}$ in case of $\mathrm{Mn}^{2+}$, beyond which there is no further increase in the adsorption. As shown in Fig.3, the uptake amount increased 100 to $400 \mathrm{mg} / \mathrm{g}$ in case of $\mathrm{Fe}^{2+}$ and from 40 to $500 \mathrm{mg} / \mathrm{g}$ in case of $\mathrm{Mn}^{2+}$ to reach the equilibrium. A shaking time of $5 \mathrm{~h}$ employed for all the equilibrium adsorption studies was enough to ensure that adsorption equilibrium was reached in each case.

\section{Sorption Dynamics:}

\section{Rate constant study:}

The kinetics of sorption of selected metal ions under investigation on carbon were studied on the basis of Lagergren equation (17):

$$
\log \left(q_{e}-q\right)=\log q_{e}-\left(K_{a d} / 2.303\right) t
$$

Where $q(\mathrm{mg} / \mathrm{g})$ is the amount of metal ions sorbed at time $t, q_{e}(\mathrm{mg} / \mathrm{g})$ is the amount sorbed at equilibrium and $\mathrm{K}_{\mathrm{ad}}$ is the equilibrium rate constant of sorption. The straight line plots (Fig.4) of $\log \left(q_{e}-q\right)$ vs. $t$ for the two metal ions indicate the validity of 
equation (1) and the process follows first order rate kinetics. The $\mathrm{K}_{\mathrm{ad}}$ values of metal ions were calculated from slopes of these plots and the results are given in Table 6.

\section{Diffusion rate constant study:}

In the model developed by Weber and Morris (1963), the rate of intra-particular diffusion is a function of $\mathrm{t} 0.5$ and can be defined as follows (17):

$$
\mathrm{qt}_{\mathrm{t}}=\mathrm{k}_{\mathrm{p}} \mathrm{t} 0.5
$$

The intra-particular diffusion rates $\left(k_{p}\right)$ were determined by plotting the amount sorbed per unit weight of sorbent $\left(q_{e}\right)$ vs. $t^{1 / 2}$, as shown in Fig. 5. The sorption rates for intraparticle diffusion, $\mathrm{K}_{\mathrm{p}}$ were calculated from the slopes of the linear portions of the respective plots with units of $\mathrm{mg}^{-1} \mathrm{~g}^{-1} \mathrm{~min}^{-0.5}$ (not the true reaction rate, but relative rates which are useful for comparative purposes) and are given in Table 6 . The two plots have the same general features, initial curved portion followed by linear portion and plateau. The initial curve portions are attributed to the boundary layer diffusion effects. While the linear portions are a result of the intraparticle diffusion effects (17) and the plateau is attributed to the equilibrium. An extrapolation of the linear portion of the plots back to the time ${ }^{0.5}$ axis provides intercepts which are proportional to the extent of boundary layer thickness. The larger the intercept, the greater is the boundary layer effect (17), and it follows the sequence: $\mathrm{Mn}^{2+}>\mathrm{Fe}^{2+}$. This follows the same order of ionic radius as shown in Table 6.

Effect of sorbent mass: Fig. 6 shows that increasing the carbon concentration increases the percent removal (R\%) to reach $100 \%$ from $1 \mathrm{~L}$ solution containing initial concentrations of $2,3 \mathrm{mg} / \mathrm{l}$ of $\mathrm{Fe}^{2+}$ and $\mathrm{Mn}^{2+}$ respectively ( sample of station I in winter ) and attained constant removal after a particular carbon concentration (optimum dosage). The minimum adsorbent dosage of $8 \mathrm{mg}$ was required for complete removal of either $\mathrm{Fe}^{2+}$ or $\mathrm{Mn}^{2+}$ after contact period of $5 \mathrm{hrs}$.

Adsorption isotherms: Adsorption data for a wide range of adsorbate concentrations are most conveniently described by adsorption isotherm such as the Langmuir or Freundlich isotherm, which related adsorption density qe (metal uptake per unit weight of adsorbent ) to equilibrium adsorbate concentration in the bulk fluid phase $\mathrm{C}_{\mathrm{e}}$. The langmuir isotherm is represented by the following equation:

$$
c_{e} / q_{e}=1 / b q^{\circ}+\left(c_{e} / b q^{\circ}\right)
$$

where $c_{e}$ is the equilibrium concentration $(\mathrm{mg} / \mathrm{l}), \mathrm{q}_{\mathrm{e}}$ is the amount adsorbed at equilibrium time $(\mathrm{mg} / \mathrm{g})$ and $\mathrm{q}^{0}$ and $\mathrm{b}$ are Langmuir constants related to adsorption capacity and energy of adsorption, respectively (18).

The linearized Langmuir plot is shown in Fig. (7). The Langmuir parameters were calculated using Eq. (3) and were found to be $\left(357 \mathrm{~g} / \mathrm{g}\right.$ and $625 \mathrm{~g} / \mathrm{g}$ for q $\left.{ }^{\circ}\right)$ for iron and for manganese, respectively. The Freundlich adsorption isotherm was also applied for the adsorption of $\mathrm{Fe}^{2+} \& \mathrm{Mn}^{2+}$ ions onto $\mathrm{RH}-57$. The Freundlich equation is presented (18) as:

$$
\mathrm{q}_{\mathrm{e}}=\mathrm{k}_{\mathrm{f}} \mathrm{C}_{\mathrm{e}}^{1 / \mathrm{n}}
$$

Rearranging Eq. (4) gives:

$$
\log q_{e}=\log k_{f}+1 / n \log c_{e}
$$


Hence, a plot of $\log q_{e}$ vs. $\log c_{e}$ enables the constants $k_{f}$ and exponent $n$ to be determined as shown in Fig. (8). The constants are listed in Table7. Although the correlation coefficients are greater than $95 \%$, they do not correlate the data as well as the Langmuir isotherm, which has consistently higher correlation coefficients as seen in Table 7.

\section{Possible working mechanism:}

The ion-exchange reaction on the silica surface is accomplished through the substitution of protons of the surface silanol groups by the metal ions from solution, as follows (18):

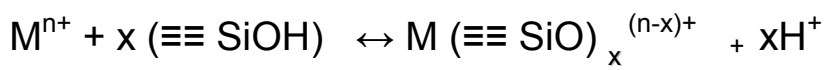

Where $\mathrm{M}^{\mathrm{n}+}=$ metal ion with $\mathrm{n}+$ charge, $(\equiv \equiv \mathrm{SiOH})=$ silanol group on the $\mathrm{SiO}_{2}$ surface and $\mathrm{xH}^{+}=$number of protons released. The cation-exchange mechanism is expected with the two metal ions as the sorbent contains large amounts of silica (> 95\%) in the ash content (31\%).

Also, since electrostatic attraction was possible negatively charged adsorbent surface and positively charged metal ion species, it seems that some electrostatic forces were involved in the adsorption process (19).

According to surface chemistry theory, $\mathrm{RH}-57$ particles and metal ions are both surrounded by an electric double layer due to electrostatic interactions (20). Based on the theory of the diffuse double layer, the thicness of the double layer is compressed by an increase in the ionic strength of the solution $(21,22)$. Such compression helps the carbon particles and metal ions to approach each other more closely. The attractive forces (such as van der Waals' forces) then become significant, leading to an increased uptake of metal ion.

Besides, two major types of chemical bindings can be responsible for the adsorption of the two metal ions onto the $\mathrm{RH}-57$ carbon (23). The covalent bonding results from the sharing of the free electron pairs between the surface oxygen atom and the metal atom or the formation of an $\mathrm{O}-\mathrm{M}$ bonding. The hydrogen bonding between surface oxygen atom and the hydrogen atom of the hydrated metal ions.

The FTIR was used to evaluate the mechanism involved. Fig. 9 shows FTIR spectra of $\mathrm{RH}-57$ carbon (original), with $\mathrm{Mn}^{2+}$ ions and with $\mathrm{Fe}^{2+}$ ions. All the spectra showed the broad bands at 3425 and $1189 \mathrm{~cm}^{-1}$ which may be due to hydrogen bonded $-\mathrm{OH}$ and $\mathrm{P}=\mathrm{O}$. Thus, the surface $\mathrm{OH}$ groups probably interact with water molecules adsorbed by the carbon surface from the environment (24). The high silica content appears in FTIR spectra, the presence of free $\mathrm{SiO}_{2}$ indicated by the presence of peak at $477 \mathrm{~cm}^{-1}$. The peak at $1100 \mathrm{~cm}^{-1}$ is very strong due to the presence Si-O asymmetric stretching bond. The peak at about $800 \mathrm{~cm}^{-1}$ is considered to be the bonding between $\mathrm{C}$ and $\mathrm{Si}$ or the overlapping of the $\mathrm{Si}$ and $\mathrm{Si}-\mathrm{OH}$ vibrations (25-27). Also, the intensity of the peak near $3425 \mathrm{~cm}^{-1}$, due to the Si-OH stretching, decreased after the uptake due to the interaction between the metal ion and the surface groups. The band in the region of $1260 \mathrm{~cm}^{-1}$ has been observed for $\mathrm{RH}-57$ carbon and shiefted to lower wave numbers with high intensity after metal removal. This band is due to stretching vibration of aromatic $\mathrm{C}=\mathrm{C}$ bond, which are polarized by oxygen atoms near one of the carbon atoms (28) or due to highly conjugated carbonyl groups (29). A new peak at $521 \mathrm{~cm}^{-1}$ appears in the spectrum of $\mathrm{RH}-57$ with 
$\mathrm{Mn}^{2+}$ which corresponds to $\mathrm{Mn}=\mathrm{O}$ stretching mode. The peak at $1189 \mathrm{~cm}^{-1}$ appears as shoulder after $\mathrm{Fe}^{2+}$ uptake with high intensity and the peak at $1096 \mathrm{~cm}^{-1}$ is shiefted to higher wave number $\left(1107 \mathrm{~cm}^{-1}\right)$ with high intensity after Mn uptake. Similar trend was also observed when oil shale was treated by sodium and potassium hydroxide (30) due to metal carbonation and metal salt vibrational modes.

\section{DYNAMIC STUDIES:}

Fig. 10 Shows that the column filled with $\mathrm{RH}-57$ carbon can be regenerated and recycled at least five times without affecting the sorption capacity of $\mathrm{RH}-57$ for $\mathrm{Fe}^{2+}$ ions ( with an initial concentration $\mathrm{C}^{\circ}=2 \mathrm{ppm}$ ). Experimentally, similar service time of $5 \mathrm{~min}$. $\left(\mathrm{t}_{1 / 2}\right)$ at $50 \%$ breakthrough was obtained even after five times of successive regeneration using $0.5 \mathrm{ml}$ of $1 \% \mathrm{KMnO}_{4} 0.06 \mathrm{M}$ concentration. The adsorption capacity was determined at this high flow rate $(11 / \mathrm{min}$.) using column experiments data by integrating the upper part of concentration versus throughput volume (Fig.10). The adsorption capacity at $\mathrm{C}_{\mathrm{e}} / \mathrm{C}^{\circ}=50 \%$ or $\mathrm{Q}_{0.5}$ ) was $1 \mathrm{mg} \mathrm{Fe}^{2+}$ per 1 gram sorbent. The total integrated amount of $\mathrm{Fe}^{2+}$ adsorbate was divided by the weight of the sorbent placed in the column to yield the adsorption capacity of $1 \mathrm{mg} / \mathrm{g}$. Since this capacity was quite lower than the Langmuir monolayer capacity $(0.357 \mathrm{~g} / \mathrm{g})$ presented in table 7 , it may be inferred that full saturation of the sorbent active sites was not achieved due to the limited time of equilibrium due to the high flow rate (one liter/min.) used under dynamic column conditions.Another factor causing the discrepancy may be the partial invalidity of the Langmuir assumption, i.e., envisaging monoenergetic adsorption on a homogeneous surface, on the inhomogeneous surface of the RH-57 as a composite sorbent. As shown in Fig.11, the column needs only $0.5 \mathrm{ml}$ of $0.06 \mathrm{M} \mathrm{KMnO}_{4}$ for each cycle and no weight loss per cycle should be considered.

\section{RECOMMENDED PROCEDURES:}

Removal of iron and manganese ions in the treatment of ground water samples using $\mathrm{RH}-57$ carbon derived from chemical activation of rice husk is significant and meaningful and can be addressed due to: i)- low cost; ii) easy operated; iii) high efficiency; iv) solve disposal problem of agro-residue (rice husk). The physicochemical parameters of ground water sample obtained from station I, before and after treatment by $\mathrm{RH}-57$ was presented in table 10 , which prove that the quality of the water is improved and the iron and manganese ions are completely removed.

\section{REFERENCES}

[1] Introducing of groundwater, Michael, Price, Chapaman, Hall 1991-1992

[2] Water Treatment Hand Book- Fifth edition- Degremont 1979.

[3] Hand book McGraw- Hill New York. (Water quality and treatment), $4^{\text {th }}(1990)$.

[4] American Water Works Association Water Quality and Treatment, $4^{\text {th }}$ (1998).

[5] American Water Works Association Water Quality and Treatment, $4^{\text {th }}(2000)$.

[6] Guidelines for Drinking Water Quality, WHO, Geneva, (2003).

[7] Ground Water, Drinking Water, U.S .Environmental Protection agency, (2004).

[8] National Research Council, Safe Water from Every Tap: Improving Water Service to Small Communities, National Academy Press, Washington DC (1997).

[9] S.D. Faust and J. V. Hunter , Principles and applications of water chemistry, John Wiley and Sons, Inc. New York, pp. 625- 643 (1967). 
[10] R. E. Machmeir, Iron in Drinking water, AG-FO-138, Minnesota Extension Service, University of Minnesota, Agriculture (1990).

[11] M. E. Flentje and R. J. Faust (ed.), Water quality and treatment- a handbook of public water supplies, $3^{\text {rd }}$ Edition. Prepared by The American Treatment Systems for Household Water Supplies-Iron and Manganese Removal, pp. 380-396 (1971).

[12] V. L. Snoeyink, and D. Jenkins, Water Chemistry. John Wiley and Sons, Inc., New York (1980).

[13] Water Quality Association Recommended industry standards for household and commercial water filters-a voluntary standard, S-200. National Headquarters and Laboratory, Lisle, Ilinois (1988).

[14] Water Quality Association Recongized treatment technique for water regulations with the application of point- of- use system, R28, National Headquarters and Laboratory, Lisle, llinois (1989).

[15] A.A.M.Daifullah, B.S.Girgis and H.M.H.Gad "Utilization of agro-residues (rice Husk) in small wastewater treatment plans, Materials Letters 57 (2003), pp. $1723-1731$

[16] J. Byrne, H.Fmarsh, In " Porosity in carbons: characterization and applications" (J.W. Patrick, Ed), Edward Arnold, London, p. 1. (1995).

[17] H.H. Tran, F.A. Roddick, J. A. O'Donnell, Comparison of chromatography and desiccant silica gels for the adsorption of metal ions-I. Adsorption and Kinetics, Wat. Res. 33, No.13, (1999), pp. 1992-1997.

[18] W.J. Weber Jr., Physicochemical Processes for Water Quality Control, Wiley, New York, 1972 (chapter 5).

[19] C. Namasivayam, K. Ranganathan, Removal of Cd (II) from wastewater by adsorption on "waste" Fe(III)/Cr(III) hydroxide, Wat. Res. 29 (1995) pp.1737 1744.

[20] M.A. Osipoowl, Surface Chemistry, Marcel Dekker, New York, 1972.

[21] M.A. Rashid, D.E. Buckley and K.R. Robertson, Geoderma, 1972, 8, p. 11.

[22] G.Müller, C.J. Radke and J.M. Prausnitz, J. Phys. Chem. ,1980, 84, p. 369

[23] M.O. Corapcio and C.P. Huang, The adsorption of heavy metals onto hydrous activated carbon, Water Research 21 (9) (1987) pp. 1031 - 1044.

[24] F. Stoeckli, A. Lavanchy, Carbon 38 (2000) p. 475.

[25] B. Stuart, "Modern Infrared Spectroscopy" John Wiley \& Sons, New York (1996).

[26] B. K. Padhid C. Patnaikb, " Development of $\mathrm{Si}_{2}-\mathrm{N}_{2} \mathrm{O}, \mathrm{Si}_{3} \mathrm{~N}_{4}$ and $\mathrm{SiC}$ ceramic materials using Rice Husk" Ceramics International 21 (1995), pp. 213- 220.

[27] D.M. Ibrahim, S.A. El-Hemaly and F.M. Abdel-Kerim " Study of Rice Husk Ash Silica by Infrared Spectroscopy" Themochimica Acta, 37 (1980), pp. 307- 314.

[28] B.K. Pradhan andN.K. Sandles " Effect of different oxidizing agent treatments on the surface properties of activated carbon" Carbon 37 (1999), pp. 1323- 1332.

[29] A. H. El-Sheikh, A.P.Newman, H.K.Al-Daffaee, S. PN. Cresswell, "Characterization of activated carbonprepared from a single cultivar of Jordanian Olive stones by chemical and physicochemical techniques" J. Anal. Appl. Pyrolysis 71 (2004), pp. 151- 164.

[30] R.A. Shawabkeh" Synthesis and characterization of activated carboaluminosilicate material from oil shale" microporous and mesoporous materials 75 (2004), pp. $107-114$. 


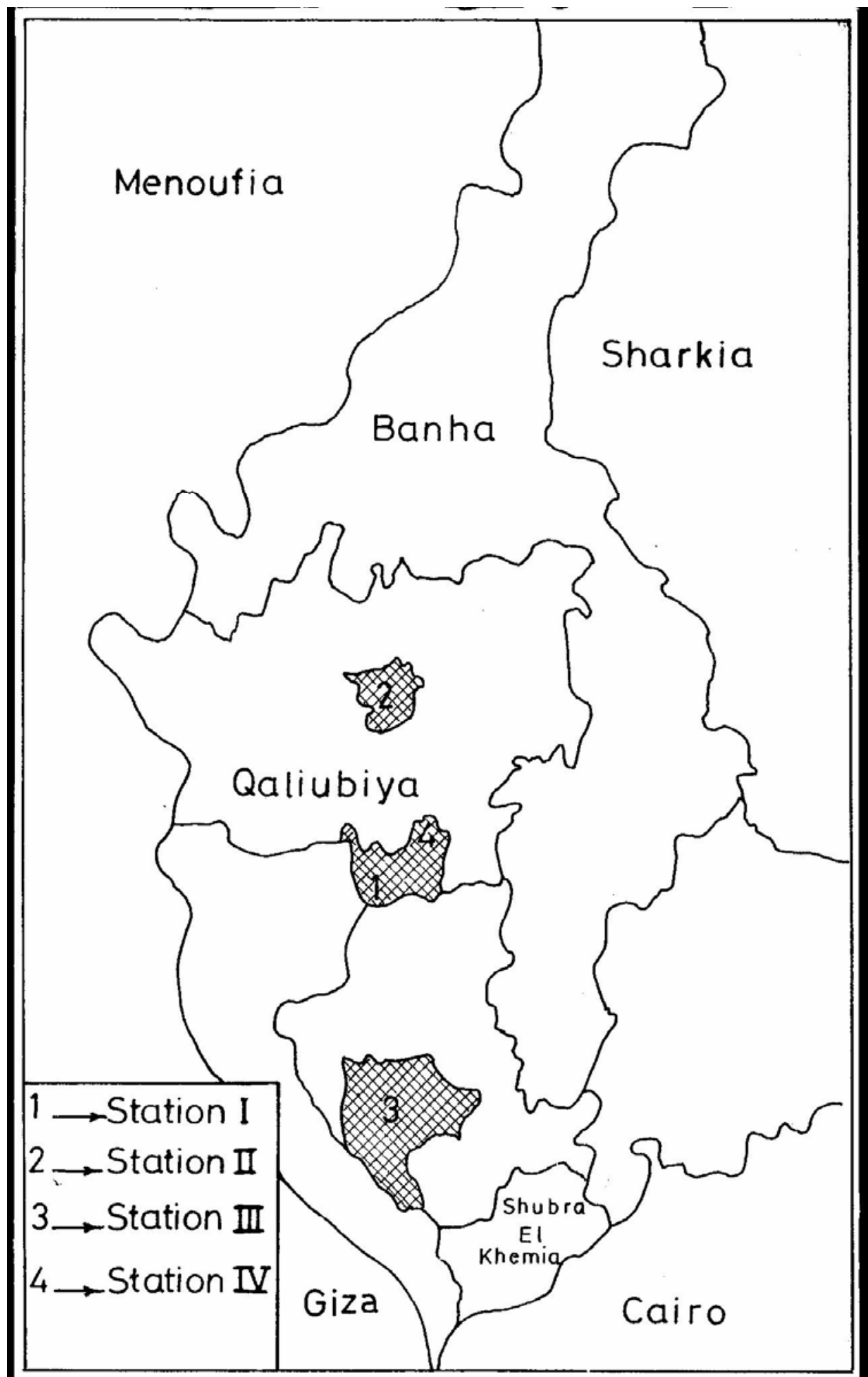

Fig(1)Location map for area under investigation 


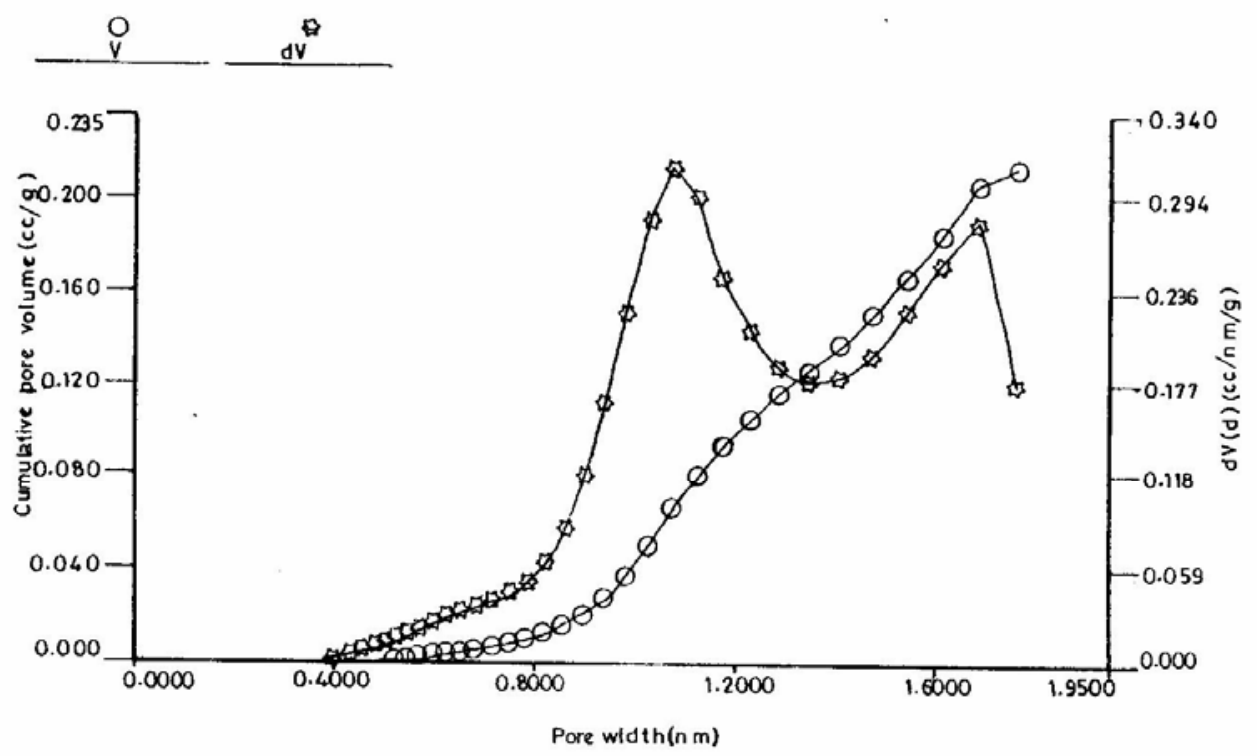

Fig. (2) the pore size distribution by DFT of $\mathrm{RH}-57$ carbon 
Fig (3) The sorbnt phase concentration of $\mathrm{RH}-57$ as a function of time for

$$
\mathrm{Fe}^{2+} \text { and } \mathrm{Mn}^{2+} \text { removal }
$$

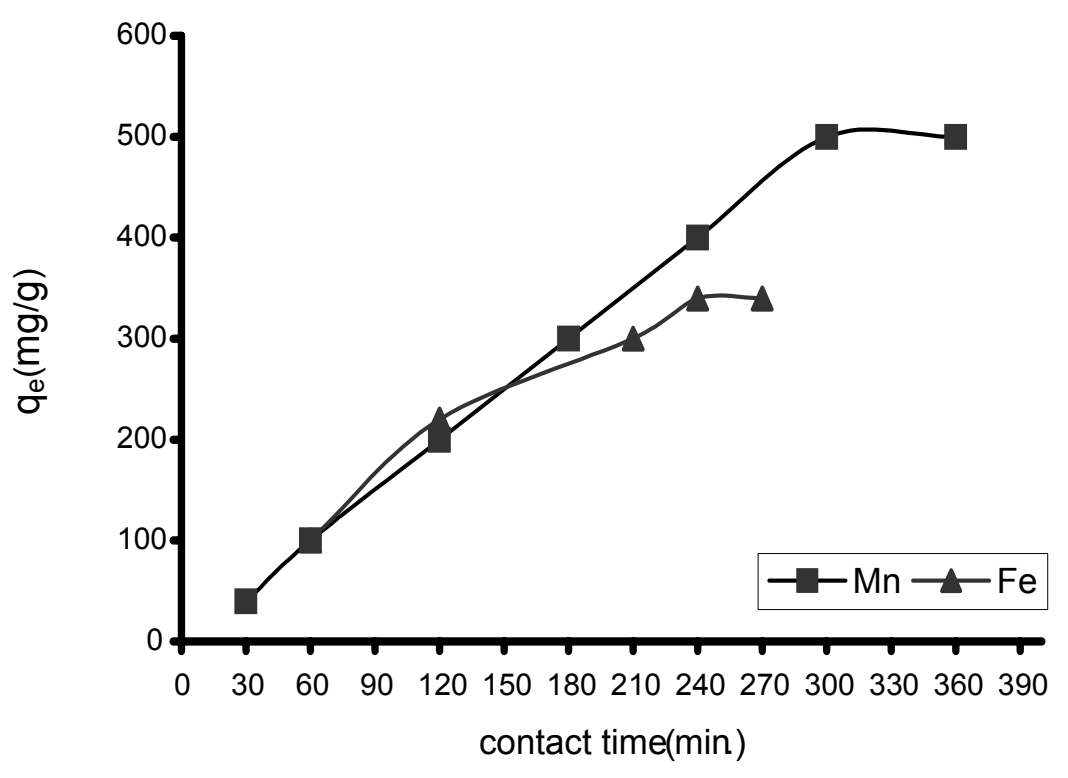

Fig(4)The sorbnt phase concentration of $\mathrm{MRH}-57(\mathrm{mg} / \mathrm{g})$ as a function of time (h) for $\mathrm{Fe}^{2+}$ and $\mathrm{Mn}^{2+}$ removal

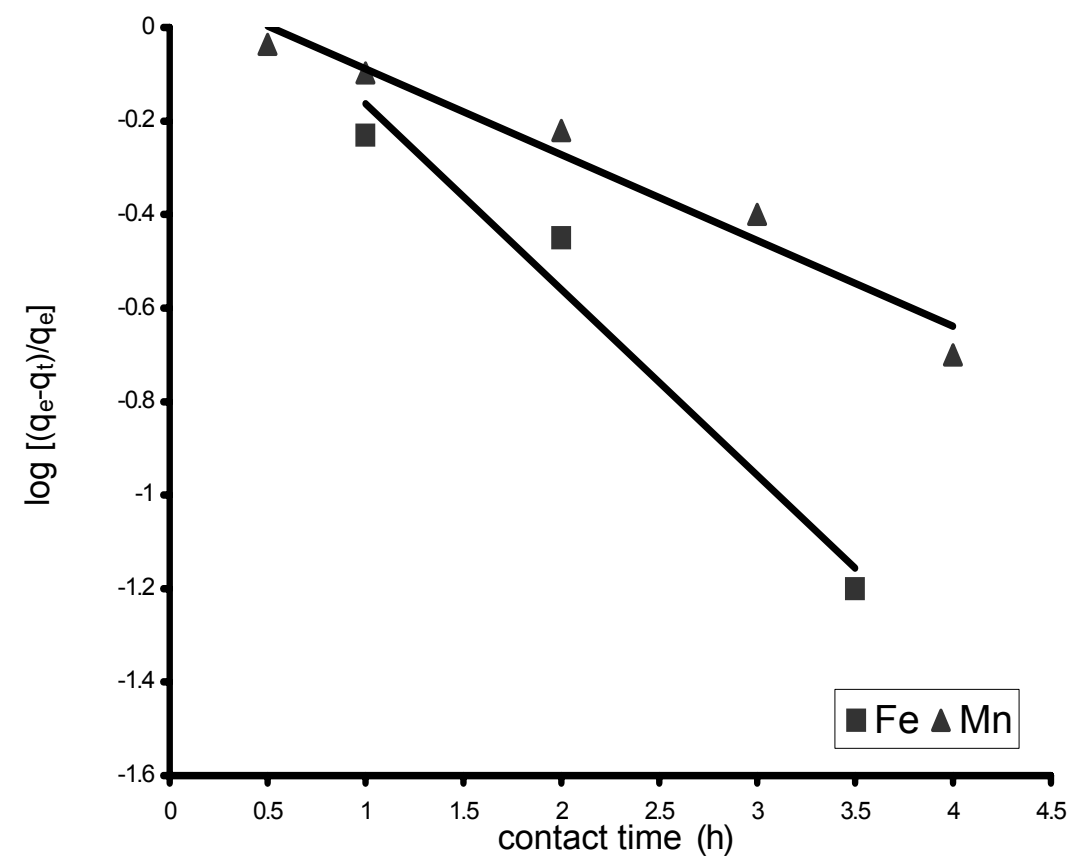


Fig(5)The sorbnt phase concentration of $\mathrm{MRH}-57(\mathrm{mg} / \mathrm{g})$ as a function of time $(\mathrm{h})$ for $\mathrm{Fe}^{2+}$ and $\mathrm{Mn}^{2+}$ removal

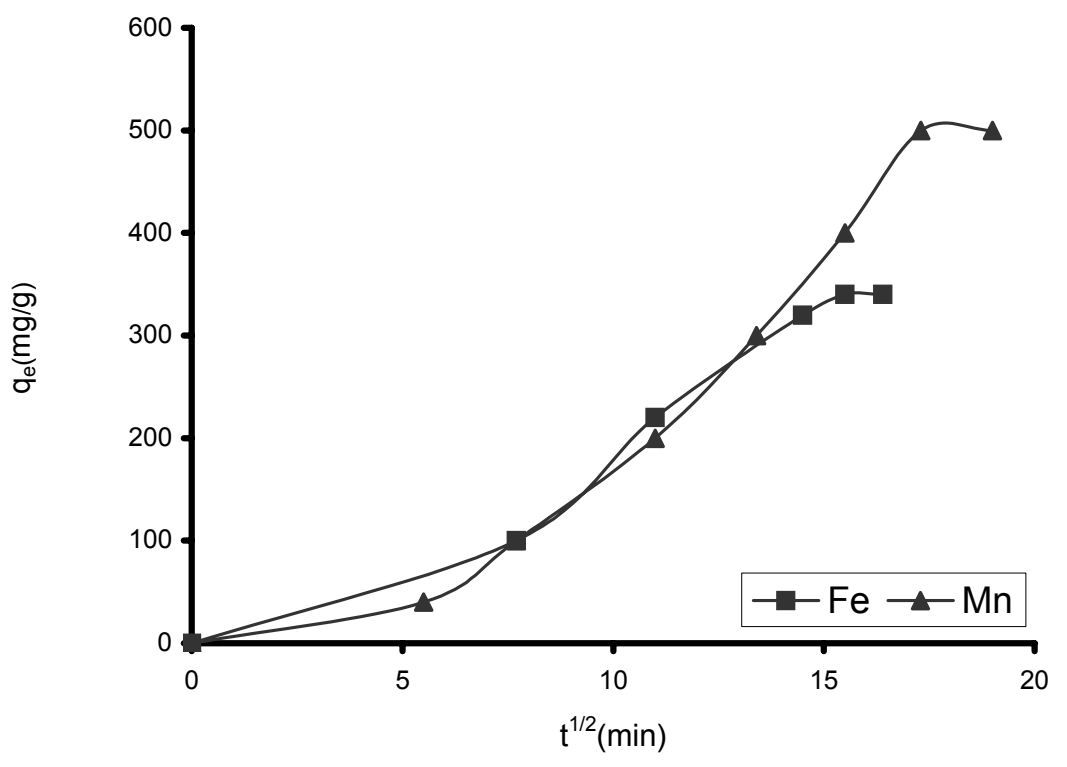

Fig (6)effect of Carbon dose on the adsorption of Fe $\quad{ }^{2+}$ and $\mathrm{Mn}{ }^{2+}$

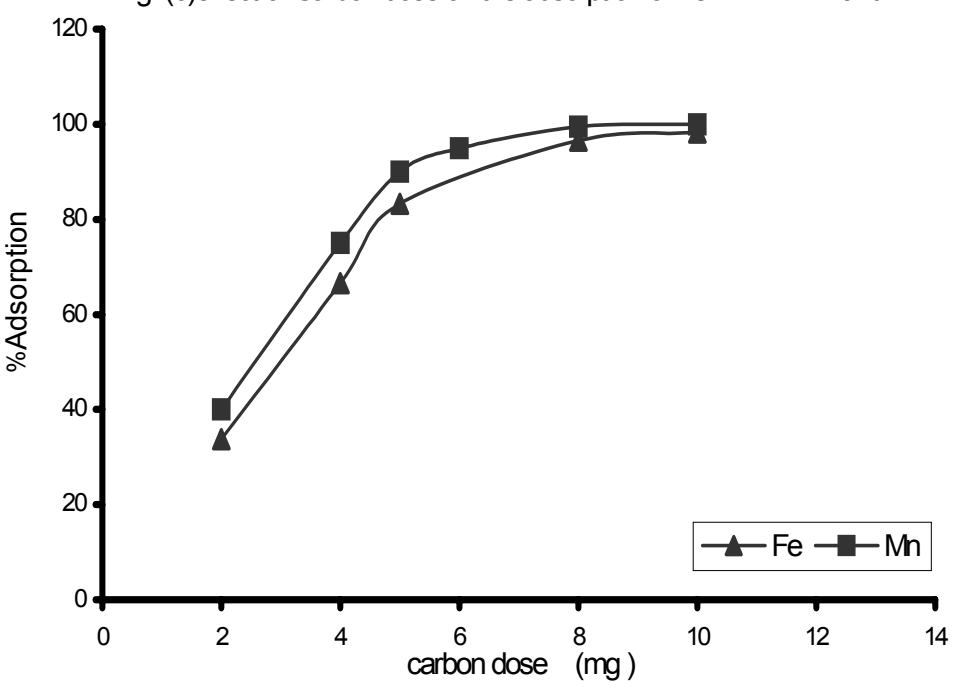


Fig.(7) langmuir plot of $\mathrm{Fe}^{2+}$ and $\mathrm{Mn}^{2+}$ by usingRH 57

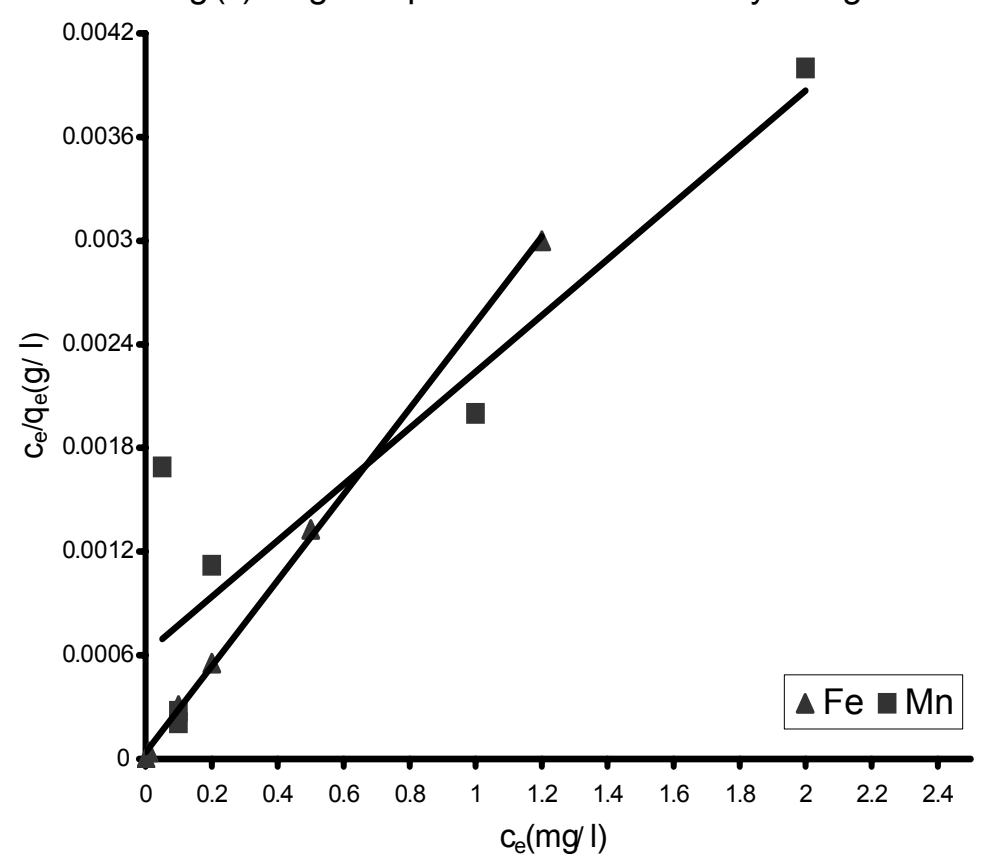

Fig. ( 8) Freundlich plot of $\mathrm{Fe}^{2+}$ and $\mathrm{Mn}{ }^{2+}$ using $\mathrm{RH}-57$

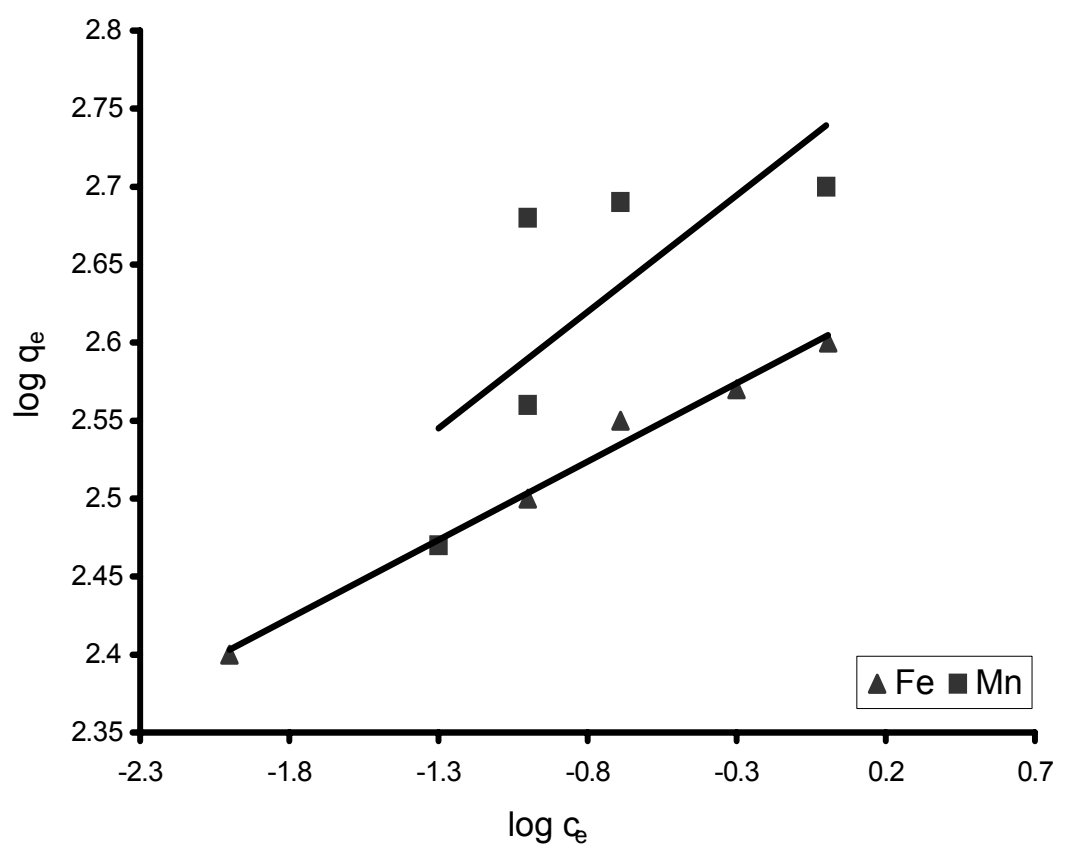




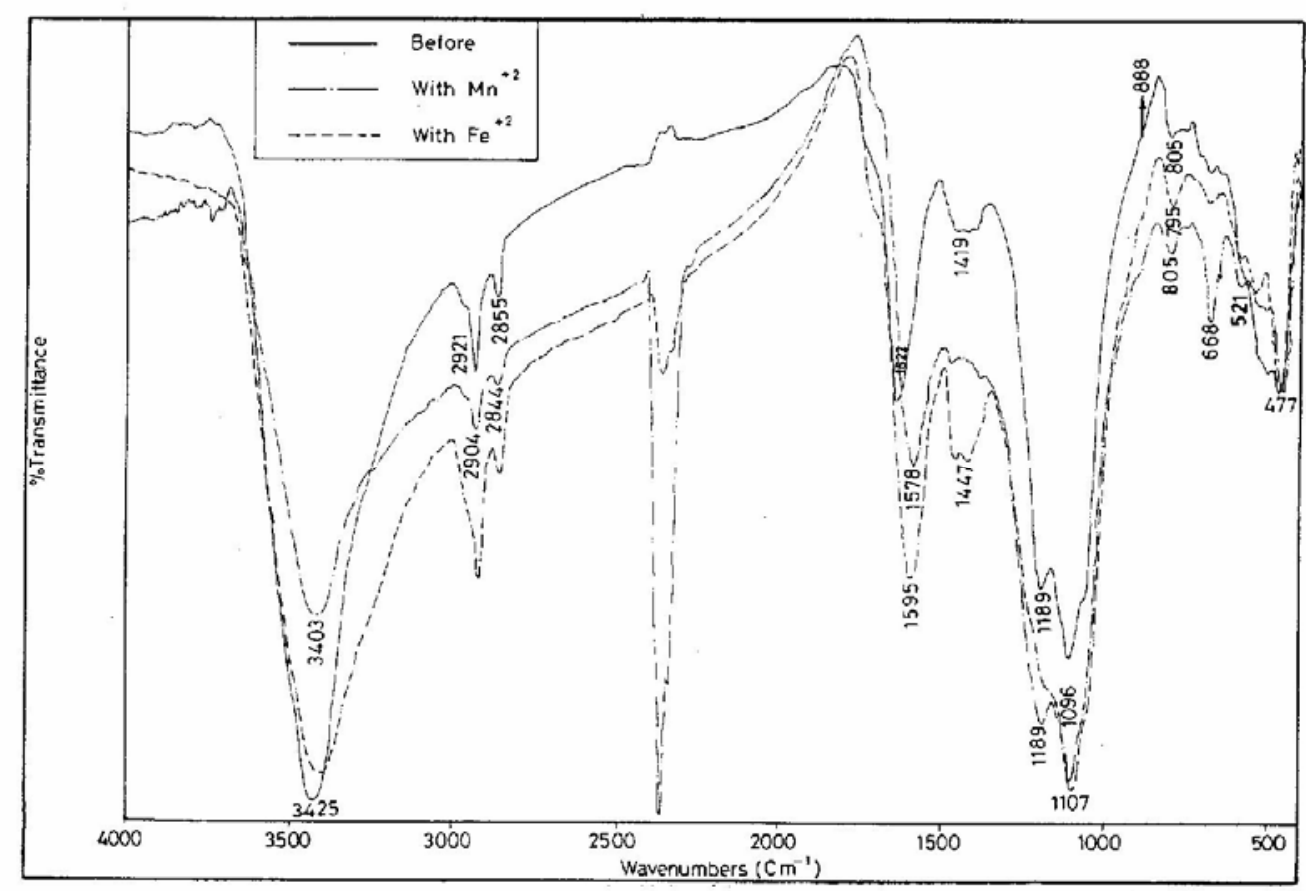

Fig (9) IR-spectra of RH-S7 carbon before and after uptake of $\mathrm{Fe}^{2+}$ or $\mathrm{Mn}^{2+}$ 
Fig .(10) ce/coversus volume of pure water in iron removal by

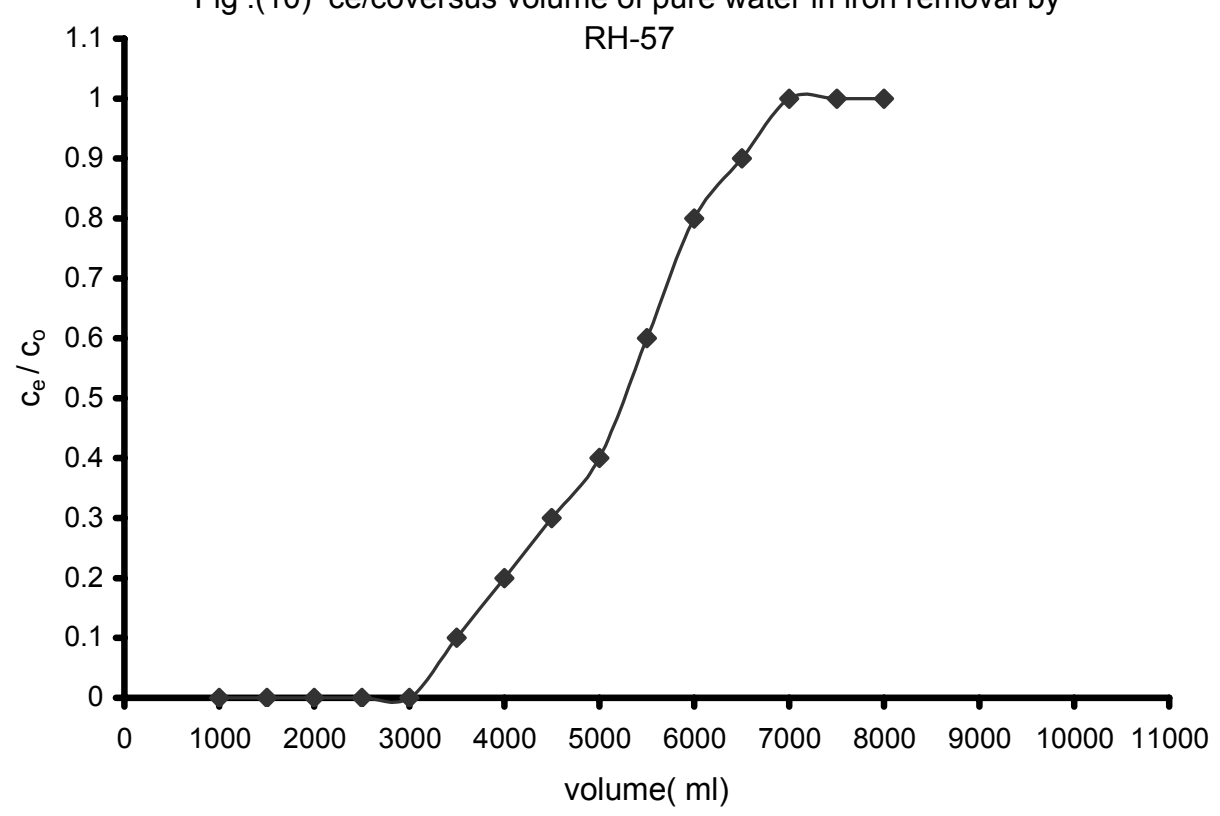

Fig(11) Elution curve of $\mathrm{RH} \quad-57$ using $0.06 \mathrm{KMnO}_{4}$

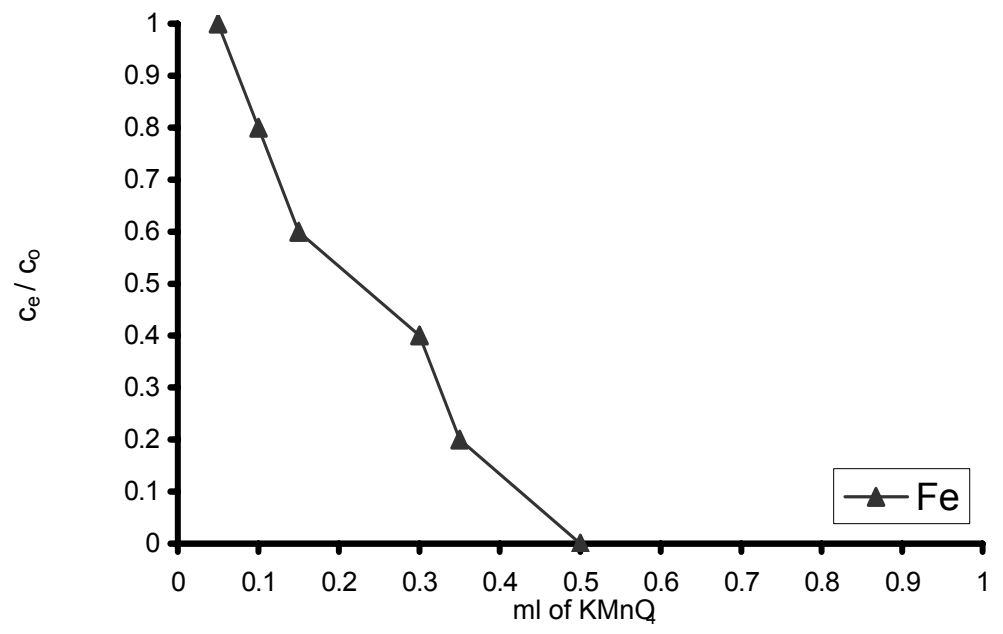


Table 1. Variations of physicochemical parameters in spring season during 2003- 2004.

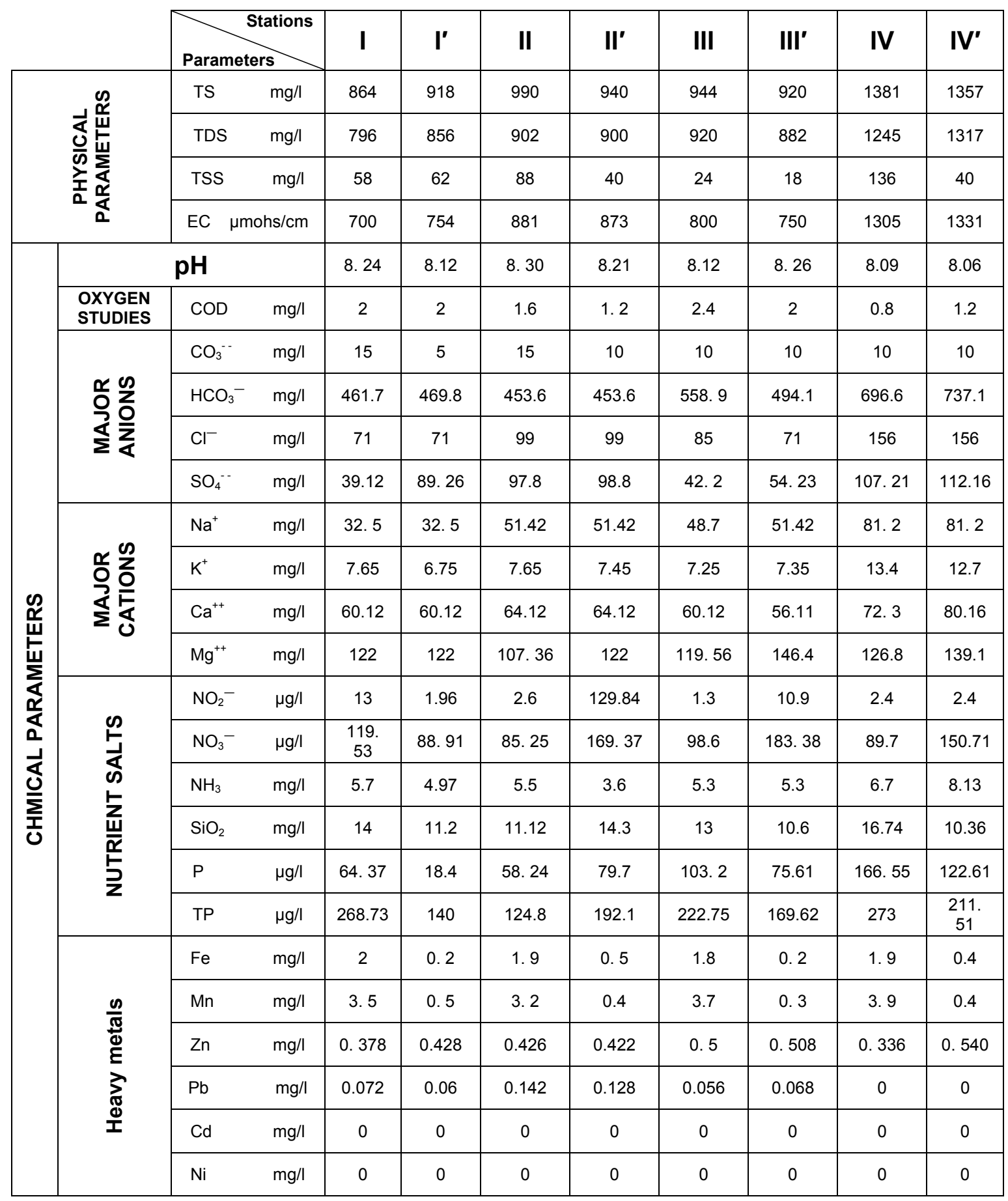


Table 2. Variations of physicochemical parameters in summer season during 2003- 2004.

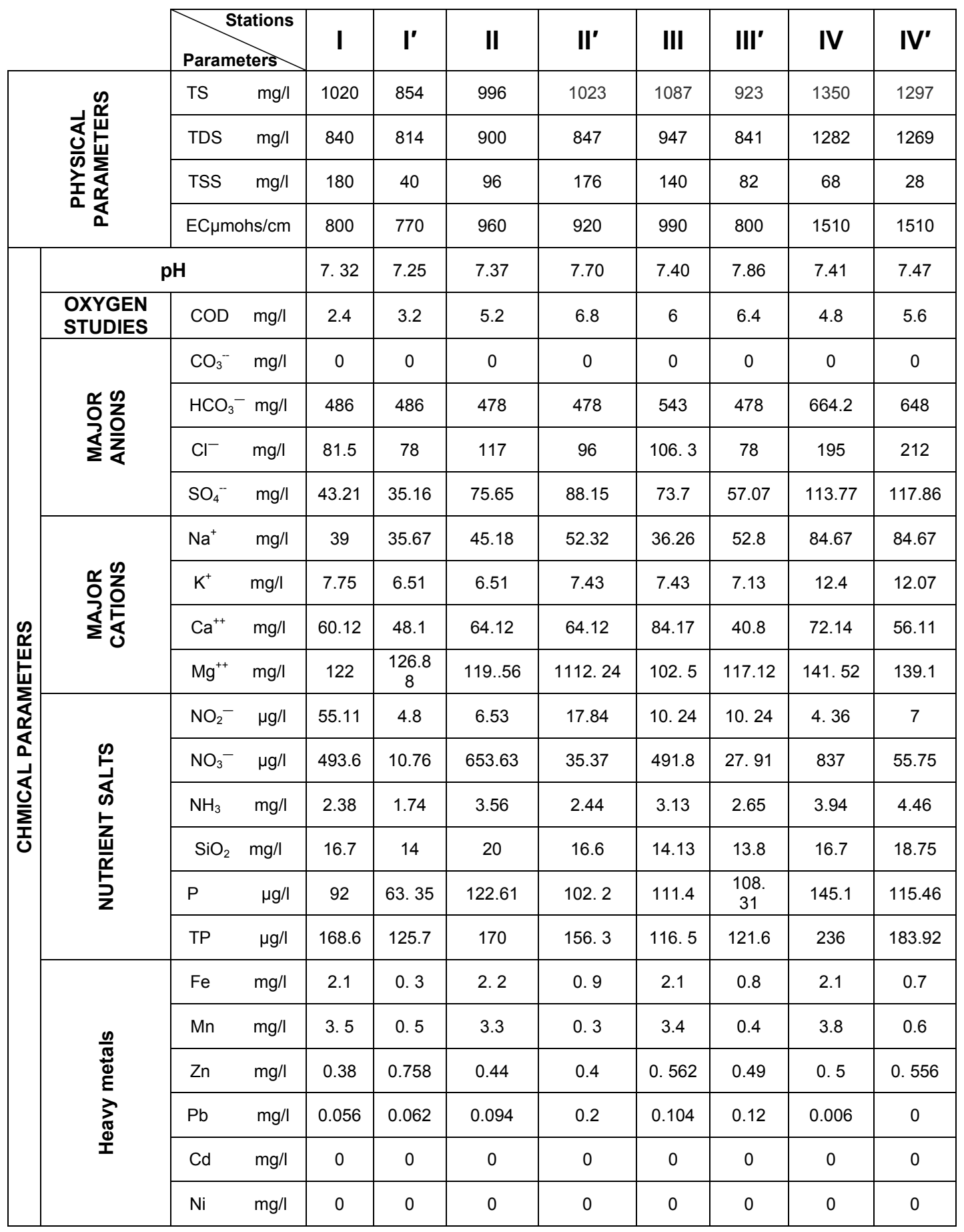


Table 3. Variations of physicochemical parameters in autumn season during 2003- 2004.

\begin{tabular}{|c|c|c|c|c|c|c|c|c|c|c|}
\hline & & $\begin{array}{l}\text { Stations } \\
\text { Parameters }\end{array}$ & I & $l^{\prime}$ & II & II' & III & III' & IV & IV' \\
\hline & 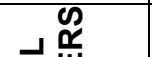 & TS $\mathrm{mg} / \mathrm{l}$ & 991 & 1034 & 1083 & 1073 & 1049 & 948 & 1714 & 1607 \\
\hline & 论㟔 & TDS $\quad \mathrm{mg} / \mathrm{l}$ & 971 & 990 & 1007 & 1005 & 977 & 884 & 1534 & 1575 \\
\hline & $2 \frac{1}{4}$ & TSS $\quad \mathrm{mg} / \mathrm{l}$ & 20 & 64 & 76 & 68 & 72 & 64 & 180 & 32 \\
\hline & $0 \frac{\pi}{2}$ & EC $\mu \mathrm{mohs} / \mathrm{cm}$ & 866 & 716 & 793 & 810 & 750 & 657 & 1380 & 1420 \\
\hline & & $\mathrm{pH}$ & 7.66 & 7.96 & 7.85 & 8.27 & 7.66 & 8.19 & 7.69 & 7.64 \\
\hline & $\begin{array}{l}\text { OXYGEN } \\
\text { STUDIES }\end{array}$ & \begin{tabular}{|l|l|}
$\mathbf{v}$ & COD $\mathrm{mg} / \mathrm{l}$ \\
\end{tabular} & 8 & 4 & 4 & 4.4 & 2.4 & 2.4 & 2.4 & 4.4 \\
\hline & & $\mathrm{CO}_{3}^{--} \quad \mathrm{mg} / \mathrm{l}$ & 0 & 0 & 0 & 0 & 0 & 0 & 0 & 0 \\
\hline & 옹 궁 & $\mathrm{HCO}_{3}^{-} \mathrm{mg} / \mathrm{l}$ & 551 & 527 & 527 & 494.1 & 567 & 494 & 770 & 794 \\
\hline & $\frac{1}{z} \bar{c}$ & $\mathrm{Cl}^{-} \quad \mathrm{mg} / \mathrm{l}$ & 110 & 90 & 100 & 110 & 84 & 70 & 234 & 228 \\
\hline & & $\mathrm{SO}_{4}{ }^{--} \quad \mathrm{mg} / \mathrm{l}$ & 97.43 & 79. 36 & 77.75 & 93.47 & 40.61 & 46.97 & 134.7 & 135 \\
\hline & & $\mathrm{Na}^{+} \quad \mathrm{mg} / \mathrm{l}$ & 45.85 & 43.3 & 48.4 & 51 & 50 & 49.03 & 92.34 & 93.62 \\
\hline$\underset{\sim}{\mathscr{c}}$ & 잉 & $\mathrm{K}^{+} \quad \mathrm{mg} / \mathrm{l}$ & 7.25 & 6. 92 & 6.05 & 6.37 & 7. 25 & 6.71 & 13 & 13 \\
\hline E् & 这 & $\mathrm{Ca}^{++} \mathrm{mg} / \mathrm{l}$ & 84.17 & 80.16 & 94.2 & 84.16 & 80.16 & 72.3 & 100. 2 & 108. 2 \\
\hline ¿্র & & $\mathrm{Mg}^{++} \mathrm{mg} / \mathrm{l}$ & 63.48 & 158.6 & 153.72 & 156.16 & 146.4 & 146.4 & 187.8 & 197.6 \\
\hline 这 & (2) & $\mathrm{NO}_{2}^{-} \quad \mu \mathrm{g} / \mathrm{l}$ & 5.01 & 21.34 & 0.65 & 38.77 & 2.4 & 10.2 & 3. 26 & 1.96 \\
\hline 文 & $\frac{5}{4}$ & $\mathrm{NO}_{3}^{-} \quad \mu \mathrm{g} / \mathrm{l}$ & 40.17 & 30.37 & 34.57 & 75.69 & 26.71 & 76.65 & 31.88 & 79.87 \\
\hline$\underline{\underline{y}}$ & $\begin{array}{l}\text { の } \\
\bullet\end{array}$ & $\mathrm{NH}_{3}$ & 6.6 & 2. 3 & 3.5 & 2.71 & 2. 93 & 2.76 & 4. 5 & 4. 2 \\
\hline U & $\underline{\underline{n}}$ & $\mathrm{SiO}_{2} \quad \mathrm{mg} / \mathrm{l}$ & 15.5 & 17.15 & 16.7 & 15.7 & 15.23 & 18.02 & 18. 3 & 17.76 \\
\hline & 点 & $\mu \mathrm{g} / \mathrm{l}$ & 54.15 & 108. 31 & 125.7 & 94 & 114 & 81.72 & 125.7 & 109.33 \\
\hline & & $\mu \mathrm{g} / \mathrm{l}$ & 143 & 147.14 & 192.1 & 187 & 149.18 & 167.8 & 262.6 & 222.75 \\
\hline & & $\mathrm{mg} / \mathrm{l}$ & 2.2 & 0.4 & 2 & 0.8 & 2 & 0.7 & 2.1 & 0.8 \\
\hline & $\frac{0}{\pi}$ & $\mathrm{mg} / \mathrm{l}$ & 3.2 & 0.4 & 3.4 & 0.4 & 3.5 & 0.5 & 3.7 & 0.4 \\
\hline & $\stackrel{\mathscr{\varepsilon}}{\varepsilon}$ & $\mathrm{mg} / \mathrm{l}$ & 0.476 & 0.366 & 0.43 & 0.52 & 0.52 & 0.48 & 0.46 & 0.516 \\
\hline & 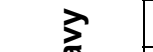 & $\mathrm{mg} / \mathrm{l}$ & 0.028 & 0.046 & 0.17 & 0.078 & 0.056 & 0.056 & 0.006 & 0.006 \\
\hline & 导 & $\mathrm{mg} / \mathrm{l}$ & 0 & 0 & 0 & 0 & 0 & 0 & 0 & 0 \\
\hline & & $\mathrm{mg} / \mathrm{l}$ & 0 & 0 & 0 & 0 & 0 & 0 & 0 & 0 \\
\hline
\end{tabular}


Table 4. Variations of physicochemical parameters in winter season during 2003- 2004

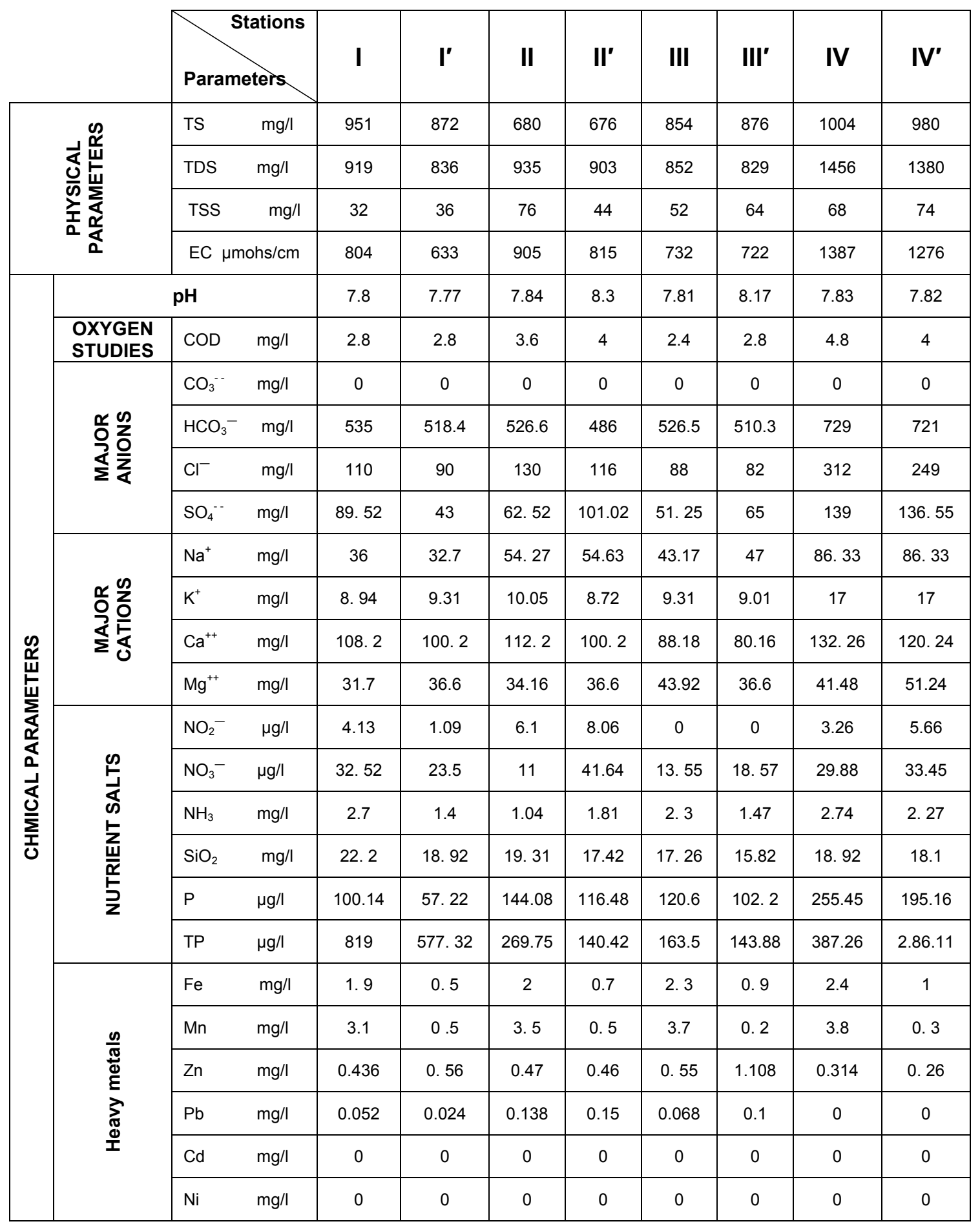


Table 5: The physicochemical parameters of $\mathrm{RH}-57$

\begin{tabular}{|l|c|}
\hline \multicolumn{1}{|c|}{ parameter } & value \\
\hline $\mathrm{S}_{\mathrm{BET}}\left(\right.$ surface area, $\left.\mathrm{m}^{2} / \mathrm{g}\right)$ & 419 \\
$\mathrm{~V}_{\mathrm{p}}$ (total pore volume, $\left.\mathrm{cm}^{3} / \mathrm{g}\right)$ & 0.213 \\
$\mathrm{~d}($ pore width, $\mathrm{nm})$ & 1.076 \\
ash content $(\%)$ & 31 \\
\hline $\mathrm{pH}$ & 3.5 \\
\hline Apparent density, $\mathrm{g} / \mathrm{cm}^{3}$ & 0.25 \\
Packed density, $\mathrm{g} / \mathrm{cm}^{3}$ & 0.33 \\
Grain size & $0.6 \mathrm{~mm}$ \\
\hline
\end{tabular}

Table 6. Sorption Kinetic parameters of $\mathrm{Fe}^{+2}$ and $\mathrm{Mn}^{+2}$ ions using $\mathrm{RH}-57$

\begin{tabular}{|c|c|c|c|}
\hline Ionic radius $(A)$ & $\mathrm{K}_{\mathrm{p}}\left(\mathrm{mg} \mathrm{g}^{-1} \cdot \mathrm{min}^{-0.5}\right)$ & $\mathrm{K}_{\mathrm{ad}}\left(\mathrm{min}^{-1}\right)$ & Metal ions \\
\hline 0.76 & 0.0322 & 0.0097 & $\mathrm{Fe}^{+2}$ \\
\hline 0.80 & 0.021 & 0.00306 & $\mathrm{Mn}^{+2}$ \\
\hline
\end{tabular}

Table 7. Langmuir and Freundlich constants of $\mathrm{Fe}^{+2}$ and $\mathrm{Mn}^{+2}$ ions using $\mathrm{RH}-57$

\begin{tabular}{|c|c|c|c|c|c|c|}
\hline \multirow{2}{*}{$\begin{array}{c}\text { Adsorption } \\
\text { system }\end{array}$} & \multicolumn{3}{|c|}{ Langmuir constants } & \multicolumn{3}{c|}{ Freundlich constants } \\
\cline { 2 - 7 } & $\mathbf{q}^{\mathbf{0}}$ & $\mathbf{b}$ & $\mathbf{r}$ & $\mathbf{K}_{\mathbf{f}}$ & $\mathbf{n}$ & $\mathbf{r}$ \\
\hline $\mathrm{Fe}^{+2}: \mathrm{RH}^{-57}$ & 357 & 363 & 98.8 & 178 & 25.4 & 99.7 \\
\hline $\mathrm{Mn}^{+2}: \mathrm{RH}^{-57}$ & 625 & 65 & 90.4 & 352 & 10.8 & 73.1 \\
\hline
\end{tabular}


Table(8) The physico-chemical parameters in ( $\mathrm{mg} / \mathrm{l})$ of ground water of station I (winter season) before and after treatment using $\mathrm{RH}-57$ carbon compared to standard specifications

\begin{tabular}{|c|c|c|c|c|c|c|c|c|c|c|c|c|c|c|}
\hline \multirow[b]{2}{*}{ Parameter } & \multirow[b]{2}{*}{$\begin{array}{l}\text { TDS } \\
\mathrm{mg} / \mathrm{l}\end{array}$} & \multirow[b]{2}{*}{$\mathrm{pH}$} & \multicolumn{4}{|c|}{ Heavy Metals } & \multicolumn{4}{|c|}{ anions } & \multicolumn{4}{|c|}{ Cations } \\
\hline & & & $\begin{array}{c}\mathrm{Fe} \\
\mathrm{mg} / \mathrm{l}\end{array}$ & $\begin{array}{c}\mathrm{Mn} \\
\mathrm{mg} / \mathrm{l}\end{array}$ & $\begin{array}{c}\mathrm{Pb} \\
\mathrm{mg} / \mathrm{l}\end{array}$ & $\begin{array}{c}\mathrm{Zn} \\
\mathrm{mg} / \mathrm{l}\end{array}$ & $\begin{array}{l}\mathrm{SO}_{4}{ }^{2-} \\
\mathrm{Mg} / \mathrm{l}\end{array}$ & $\begin{array}{c}\mathrm{Cl}^{-} \\
\mathrm{mg} / \mathrm{l}\end{array}$ & $\begin{array}{c}\mathrm{HCO}_{3}^{-} \\
\mathrm{mg} / \mathrm{l}\end{array}$ & $\begin{array}{l}\mathrm{CO}_{3}^{-} \\
\mathrm{mg} / \mathrm{l}\end{array}$ & $\begin{array}{l}\mathrm{Ca}^{2+} \\
\mathrm{mg} / \mathrm{l}\end{array}$ & $\begin{array}{l}\mathrm{Mg}^{2+} \\
\mathrm{mg} / \mathrm{l}\end{array}$ & $\begin{array}{l}\mathrm{Na}^{+} \\
\mathrm{mg} / \mathrm{l}\end{array}$ & $\begin{array}{c}\mathrm{K}^{+} \\
\mathrm{mg} / \mathrm{l}\end{array}$ \\
\hline (a) & 783 & 7.5 & 2 & 3 & 0.1 & 0.5 & 80.3 & 129.9 & 567.1 & 3.1 & 83.5 & 110.2 & 54.7 & 9.3 \\
\hline (b) & 750 & 7.4 & 0 & 0 & n.d & n.d & 77 & 125 & 550 & 3.4 & 76 & 115.3 & 55.7 & 9 \\
\hline \multicolumn{15}{|l|}{ Specification } \\
\hline Egyptian standard & 1200 & $6.5-9.5$ & 1 & 0.5 & 0.05 & 5 & 400 & 500 & n.d & n.d & 200 & 150 & 200 & n.d \\
\hline WHO & 1200 & $6.5-8.5$ & 0.3 & 0.1 & 0.05 & 5 & 400 & 250 & n.d & n.d & n.d & n.d & 200 & n.d \\
\hline Europian Standard & n.d & $6.5-8.5$ & 0.3 & 0.05 & 0.05 & 3 & 25 & 25 & n.d & n.d & n.d & n.d & $150-175$ & 12 \\
\hline US Standard & 500 & $6.5-8.5$ & 0.3 & 0.05 & 0.05 & 5 & 250 & 250 & n.d & n.d & n.d & n.d & n.d & n.d \\
\hline
\end{tabular}
$\mathrm{a}=$ before treatment
$\mathrm{b}=$ after treatment using $\mathrm{RH}-57$
n.d $=$ not detected 